\title{
Renewable Energy for Rural Areas of Bolivia
}

\begin{abstract}
This paper analyses the current status of rural renewable energy in Bolivia and provides and employs an analysis framework to study the network of stakeholders that determines the adoption, absorption and diffusion of renewable energy technology. The study, moreover, illustrates the impact and implications of traditional indigenous knowledge on the local entrepreneurial ecosystem.
\end{abstract}

\section{Introduction}

In the near future the access to basic needs in a world of 7 billion people will be strongly influenced by the $80 \%$ of humanity living in the developing world. Their consumption patterns and their approach to sustainability will undoubtedly shape the global economy. The understanding of the evolution of the energy use in the so-called South of the world is crucial to achieving global sustainability. In this scenario it is relevant to formulate a very stimulating hypothesis: emerging countries are a fruitful reservoir of innovations and sustainable practices [1]. It would not be surprising to discover that sustainability and resilience in the developing world still rely on social values and traditional knowledge [2]. Nevertheless, it is intriguing thinking that emerging economies, at least potentially, might trigger a new alternative frame, it becomes extremely important to quantify the extent of such a change [3]. The last decade has seen an increasing connection between emerging countries like China, Latin America and some African countries. China is already exchanging infrastructures for natural resources in Africa and Brazil is playing a similar role with its neighbours [4]. As they share expectations and problems, it would be interesting to understand the process of sustainable practices diffusion between these countries. Even more important might be to find out if those practices can potentially have a disruptive impact on industrialised countries leading to what Seely-Brown calls Innovation blowback [5]. Recent literature focuses on the potential of developing countries in adopting and deploying renewable energy (RE) especially in context where geographic conditions and isolation represent serious constrains for the development of conventional energy supply lines $[6,7]$. Moreover the increasing demand of energy in rural areas represents a continuous challenge in emerging economies like India and China [8], [9]. Those countries have been already financing rural electrification programmes to reach the most isolated areas of their immense territory [10]. Many other countries in Asia and Africa are following the same trend [11], [12], [13]. Furthermore decentralized renewable energy, such as standalone solar systems, will likely play a fundamental role in expanding rural energy access [14]. The present paper describes the case of Bolivian renewable energy sector. The study adopts a systemic approach with the idea of covering the main stakeholders that influence the diffusion and deployment of renewable energy technology in the rural areas of Bolivia. The first part of the paper is dedicated to illustrate the institutional and social context of the country. The second part describes the main rural electrification programmes that have been carried out in the last two decades and their impact on the local entrepreneurial ecosystem. Finally, the last part focuses on the influence of traditional knowledge on the adoption and effectiveness of renewable energy among indigenous communities. 


\section{The current status of energy in Bolivia}

Bolivia, long one of the poorest Latin America countries, still misses a real industry and depends in many sectors on foreign import. The economy of the country is prevalently based on subsistence farming, the production of hydrocarbons and mining industry $[15,16]$. In the last 20 years, the decline of the mining industry, as well as the drop of price of tin, yielded to a fast development of the industry of fossil fuels. However, though Bolivia owns one of the biggest fields of natural gas in the world, $36 \%$ of the population (about 3.3 Million people), especially in rural areas, do not have access to electricity [15]. High inequalities and a weak institutional framework do not allow the correct exploitation of the rich natural resources of the country, hampering industrial development and forcing most of the people to live under the poverty threshold. The energy sector, once an absolute monopoly of the electric state company $\operatorname{ENDE}^{1}$ (Empresa Nacional de Electricidad), is now fragmented into local private companies, while the hydrocarbon sector is ruled by the oil company YPFB (Yacimientos Petroliferos Fiscales Bolivianos). As there is no big hydroelectric dam, gas turbine plants and thermoelectric plants produce about the $82 \%$ of Bolivian's electricity [15].
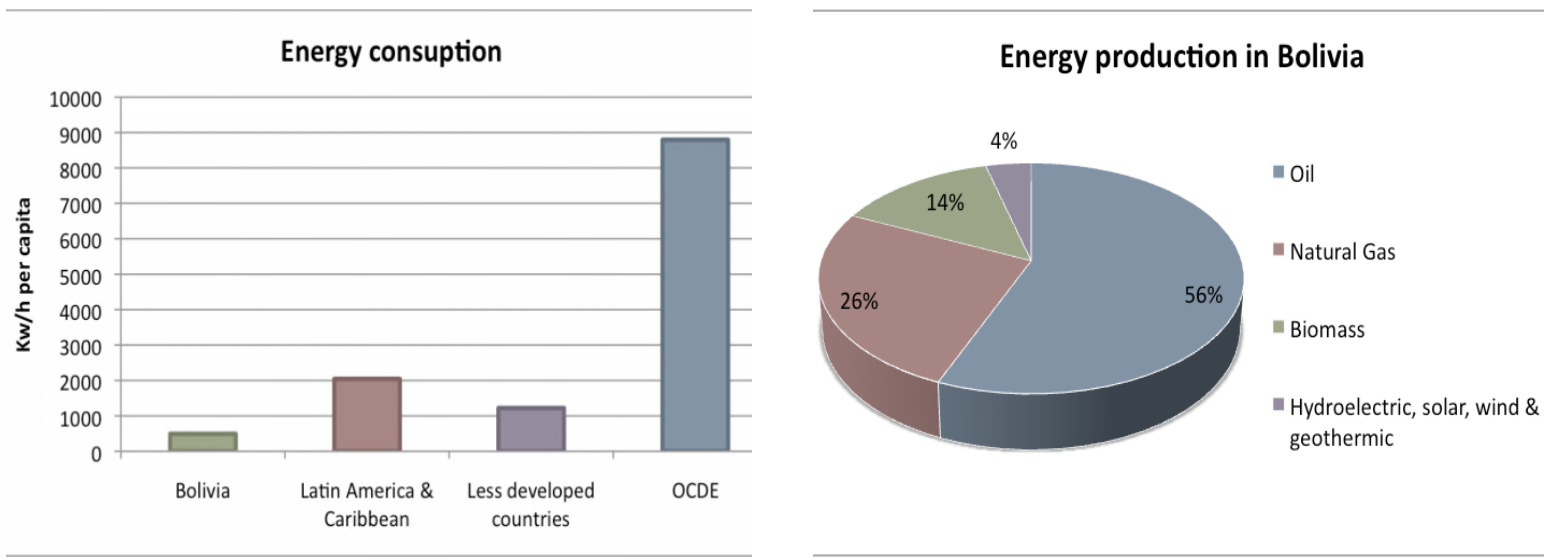

Figure 1 Source: original Based on [15]

Due to the lack of industries, Bolivia is not a big energy consumer (just $493 \mathrm{Kwh}$ per capita compared to the $8795 \mathrm{Kwh}$ per capita consumed by OCDE Countries). As it is possible to see in Figure 1, Bolivian energy consumption is also much lower than other developing regions. In terms of carbon emission, Bolivia emits just 0.8 tons per capita compared to the 11.5 tons of OECD countries (Figure 2).

\footnotetext{
${ }^{1}$ ENDE webpage: www.ende.bo
} 

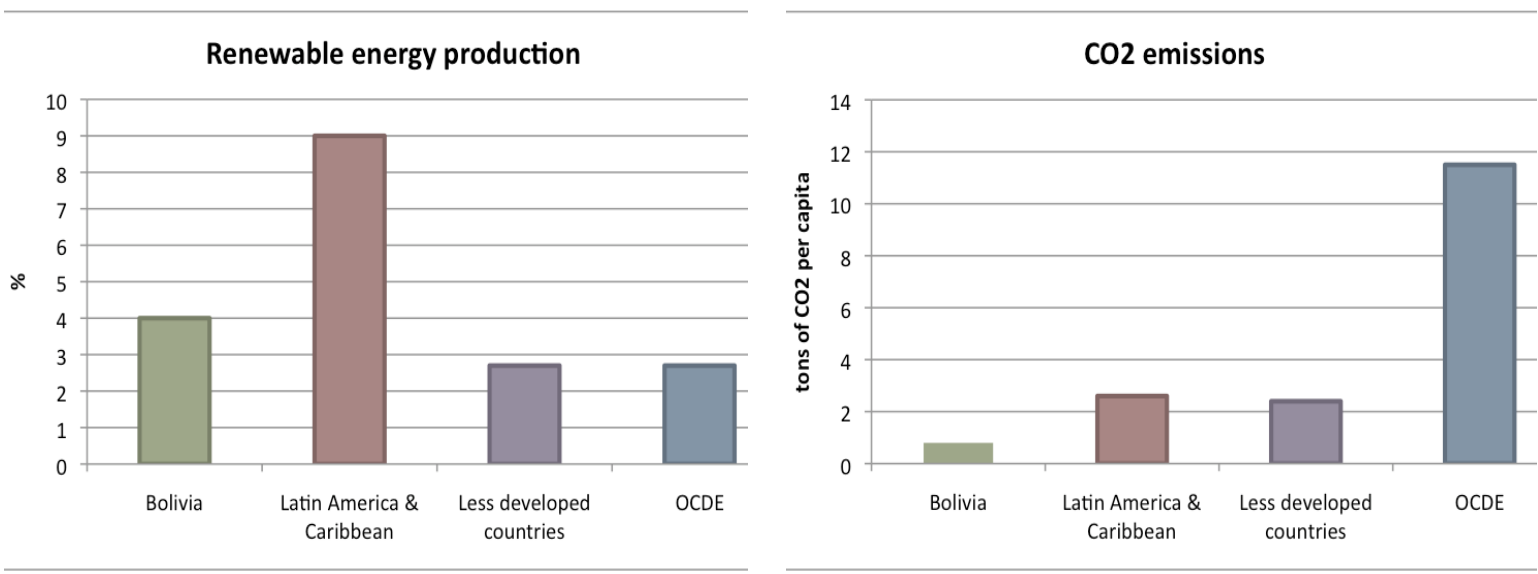

Figure 2 Source: original Based on [15]

Although energy production in strongly centralized, in the last 20 years the environmental awareness in this field has been increasing continuously. The weaknesses of the electric network forced many different Organizations like universities, NGOs and local enterprises, to search alternative solutions. Moreover, we must say that, though the lack of infrastructures and funding exists, the Bolivian university system presents many levels of excellence especially in the mining sector, and in energy and environmental management. The rule of public university has been crucial in the process of interconnection of international development actions and the local entrepreneurial environment.

However a remarkable shortcoming is represented by the fact that in Bolivia a real policy of innovation does not exist [16]. All the innovative initiatives, indeed, are carried out or promoted by foreign actors. In the specific case of RE, international cooperation plays a fundamental role in the transfer of technology as well as in improvement of local capabilities. On the other hand, the international action in the last decade in Bolivia has been strictly related to public institutions especially in the formulation of a strategy to spread sustainable use of energy in rural zones [17]. In this context it has been shown that Bolivian society and traditional habits are fundamental for the functioning of the system. In fact, Bolivia is a country where traditional knowledge is extremely rich and important for social life. Every attempt to promote a sustainable development that does not take into account this element is bound to fail.

\section{Material and Methods}

\subsection{Case study design}

The aim of the following sections is to describe the methodology used to study the nascent sector of renewable energy in Bolivia. A special effort is dedicated to illustrate i) the purpose of study case, ii) what the case attempts to find out and iii) methods and data used to support the findings. The case study presents a double nature composed by an exploratory intention and an illustrative function:

- Exploratory purpose: The work aims to understand the dynamic of the diffusion knowledge in the context described in order to formulate more general considerations. 
- Illustrative purpose: The case points to show that it is possible to use the Innovation System approach to improve the sustainability in developing industry. Moreover the work aims to prove that it is possible to design a cooperation policy based on this statement.

The design of the case study is composed of two fundamental parts: Data collection and an analysis phase. The data collection phase encompasses the stage of problem formulation and the definition of the research questions. That phase was designed starting from a preliminary overview of the Bolivian energy sector that raised several interrogatives regarding not only economic aspects but also socio-political issues. Once the data collection was completed, the analysis stage tried to build a coherent connection between the empirical evidence and the propositions advanced in the first phase. In particular the case study has been designed to shed light on the following issues:

- Analysis of Innovation: In details exploration of the 3 dimensions of eco-innovation in the Bolivian renewable energy sector (Technological, institutional, social).

- Analysis of Innovation System: Analysis of the connection between the actors of the "proto-Innovation System" of the renewable energy sector. How is the knowledge produced? How does it flow and where are the bottlenecks of its diffusion?

- Development Policy: What is the impact of international cooperation for development on the sector? Which actions improved the functioning of the system and which ones jeopardized it? What are the future challenges and how is it possible to implement innovative actions?

\subsection{Sources of evidence}

The case study is based on three sources of data: i) Interviews and surveys, ii) Documents, iii) Direct and participant observation. The information collected comes from personal contacts developed in situ and indirect contacts provided by the latter. The data collection, indeed, can be split into two separate moments. The first phase dates back the period between 2006 and 2008. In this early stage, the author was directly involved in a project of international cooperation and had the opportunity to collect documents and direct information in situ. The second phase of collection was carried out in the first half of 2010. In this phase, taking advantage of local personal contacts, the author established a network of people to be interviewed. Each contact provided unstructured information through oral interview or survey, specific documents and further personal contacts. The methodology gave room to a snowball effect that allowed me to reach 12 subjects involved in different areas relevant for the study. A complete description of the employment positions of the persons involved in the study, and their personal contacts, are reported in Appendices.

\subsubsection{Interviews and surveys}

Taking advantage of the personal relationships developed on the field, the technique of semi-structured interviews was largely preferred. From April 2010 to June 2010, the author contacted 12 people belonging to Bolivian Firms, Public Administration, International and local NGOs, and local and foreign Universities. The author preferred to carry out personal interviews by phone. In the case in which the subject was unavailable for a telephone 
interview, an open questionnaire was submitted covering the main aspects of the research. The questionnaires were formulated according to three different models: One addressed to NGO personnel, one for public administrators and one for academics. In some cases the information provided by the questionnaires was insufficient, the answers, indeed, were misleading or too short. In this case the author was compelled to ask for further information or specific documents. In many cases the documents provided by the interviewees were even more important than the interviews themselves. In fact, the information contained in corporative documents, reports and project descriptions complemented the personal views of the interviewees. The semi-structured interviews aimed to encompass all the issues raised by the research questions. Part of the material and documents used in the following sections was collected in the field of the case study. Indeed, from September 2006 to February 2008 the author was involved in the project Norte Potosi (North of Bolivian department of Potosí), funded by the Italian Ministry of Foreign Affairs, as technical personnel. The project, designed by the Italian NGO Ricerca e Cooperazione (Research and Cooperation) in collaboration with the local organization Energética, pointed to improve the quality of public social services in a disadvantaged region, among the poorest areas in Bolivia. In particular the project focused on the areas of health and education through the installation of 96 photovoltaic systems (PVS) in 76 schools and 20 rural health posts, to provide electricity for lighting, storage of vaccines, radio, and water pumping, as well as the installation of 20 systems for heating water using solar energy [18].

\subsection{The network of stakeholders}

The present review is based on a systemic analysis of the network of stakeholders involved in the development of renewable energy solutions for rural zones. The concept of a network is fundamental in the understanding of the dynamic of adoption, absorption and diffusion of renewable energy technology, especially when one wants to modify the local environment through the tool of policy [19]. Such an approach has been used successfully to analyse socio-technical transition in several developing countries [20],[21],[22]. In the Bolivian case it is possible to identify the four main groups of stakeholders:

- Universities: Academic institutions produced several experimental spin-offs in the field of photovoltaic cells and solar energy. Some of them turned quickly into SMEs, which currently employ several skilled people. Moreover, since 5 years ago the most important universities in the country (La Paz and Cochabamba) included graduate courses in their academic programs, which focused on planning and management of renewable energy.

- Local Enterprises: The first enterprises were the result of successful university spinoffs. However, after almost 15 years of activity, the demand of skilled personal is continuously increasing. Indeed, only in the photovoltaic sector, more the 40 microenterprises have been created to guarantee the maintenance of the 20,000 systems installed.

- NGOs: Local and foreign NGOs have been crucial in building a network of subjects that allowed the diffusion of renewable energy services. Those organizations play as an interface between local communities, micro-enterprises and academics. Nevertheless foreign NGOs often guaranteed the economic feasibility of the projects. 
- National and Local institutions: Even though national government has been directly involved in many projects, it is still missing the necessary legislative framework to foster a national renewable energy market. Furthermore, local municipalities, which have been participating in several projects providing funds and infrastructures, played a special role in the diffusion of renewable technology among the people.

\subsection{Technological, Institutional and Social Dimensions}

According to the Bolivian Cultural Institute (Instituto Boliviano de Cultura, IBC), about $80 \%$ of the population has an indigenous origin. The native population is divided into approximately 40 ethnic groups [23]. The organization of daily life is still strongly based on the traditional pattern of production. However this particular melting pot could be used to channel the enormous diversity and richness of the country to improve the quality of life of its inhabitants and, at the same time, guarantee social and environmental sustainability. Bolivia is not an innovative country and its economy is not particularly dynamic. According to the World Economic Forum, Bolivia occupies $18^{\text {th }}$ place in the innovation index ranking in Latin America. In the region only Paraguay performs worse in terms of innovation [24]. Bolivia does not have a developed industry able to carry out R\&D projects, and most of the technology is imported. As the case of the RE sector shows however, a big effort is needed to adapt the imported technology to the local reality. Actually, most of the projects carried out have been modified in their original design because of the interactions with final users (learning by interacting). Even though Bolivia is becoming one of the most important exporters of energy in the Mercosur, the majority of the rural population has no access to electricity [25]. According to Miguel Fernandez, director of the local NGO Energética, in such a context, renewable sources (solar, micro-hydro, wind and biomass) appears to be the best way to meet the energy demands of small isolated rural areas, characterized by high population dispersion, difficulties of access, diversity of ecosystems, poor integration and with no opportunity of integration in national markets. For those reasons, the use of alternative sources of energy was encouraged by public actions to solve the problem affecting the backward rural areas of the country. Consequently the present study focuses mostly on the technologies directed to meet the demand of the countryside. Those technologies are basically photovoltaic and solar systems, and micro-hydroelectric plants. The use of renewable sources in the context above described affects the productive system at several different levels. From an innovation perspective we can identify three fundamental dimensions:

\subsubsection{Technological dimension}

The majority of the innovations introduced in the RE market in Bolivia should be classified as new for the country [26]. However the most important contribute to technological innovation seems to be the adaptation of existing technology to local necessities. In particular, photovoltaic and solar technologies were adapted to local spare parts and atmospheric conditions (Andean plateau, rain forest, wetland, etc.). However, according to prof. Eduardo Lorenzo, professor at Universidad Politécnica de Madrid (Madrid Institute of Technology), the absorption capacity of local personnel has been much more important than technological adaptation. "A good cable is a good cable in any condition - he claims rather than choosing a cheaper solution it is important to invest in building local capability". Nevertheless, more than the pure technological innovation, in the case of many developing countries the process of quality control seems to be crucial. This capability resides basically 
in the ability to choose appropriated technology, spare parts and proper planning. In other words, the development of technical and scientific skills results to be more useful than the mere transfer of prefabricated technology. In the case of domestic services, like solar kitchens, ovens and heating, the users contributed to the designs of new improved prototypes. Moreover, few experimental micro-hydroelectric plants have been carried out with success thanks to the participation of the local community.

\subsubsection{Institutional Dimension}

The most important advance in the country's institution framework has been the introduction of sustainability awareness. For the first time in Bolivia there is a debate about the eco-efficiency and sustainability of development $[27,28]$. This fact is certainly due to the involvement of local municipalities, local universities and the final users in the process of diffusion and adaptation of sustainable technology. However, a lot of work is still needed to try to find out a specific pattern of development able to combine a reduction in poverty with sustainability goals. The post-colonial history of Bolivia has often precluded the civil society from the possibility of designing or perpetuating its own institutions. This represented a strong limitation of freedom but also a constrain to the development of local potential [29].

\subsubsection{Social Dimension}

Indigenous tradition in Bolivia is characterized by a systemic vision of Planet Earth. The ancestral linkage of the indigenous world to the land (Pachamama) is crucial to understand how those people interact with the environment. They feel part of an intertwined web, which connects people, animal and natural resources. In recent years the Bolivian government has been promoting the concept of Buen Vivir (living well) versus the dogma of vivir mejor (living better) of industrialized countries. This conception of the world considers the endless race for economic growth, characteristic of Western countries a big danger and incompatible with the equilibrium of the planet. This view is well described in the following words:

"Being part of nature, being uywas (children) of Mother Earth, being sisters and brothers of the wind, stars, plants, stone, mist, mountains, birds, pumas, we, as human beings, have to comply with the Laws of Nature, meet Mother Earth, caring for Mother Earth [...] [30]."

The way this world is accepting modern technology is fundamental to explore alternative and innovative patterns of development. The traditional community is often indicated as the central character of that challenge:

"[...] to comply with the Pachamama, the Mother Earth, we have to raise the energy of our communities, promote creativity, enthusiasm and take initiatives for joint action from our own communities and, if we have this opportunity, also with support from our own governments, to assume our responsibility to build a Living Well for all within the limits that the health of our Mother Nature permits".

Actually the role played by local communities in the diffusion of RE technologies seems to be extremely important. The success of state funded projects of rural electrification is often determined by the participation of local communities. Such social groups are crucial not only in rural areas but also in peripheral urban zones. The social organization in the rural world, 
indeed, is often reproduced in many urban contexts and strongly influences the economic life of several cities in Bolivia. The rural community reorganizes itself in the urban environment by looking for new sources of income and creating a web of relationships that in part are shaped on the original organization of rural society. That undergrowth of informal economic activities represents an almost unexploited potential for local development.

\section{Institutional framework, Local firms, and social context}

The diffusion of RE technologies in Bolivia has been hampered by several institutional barriers. However in the last two decades the Bolivian state unexpectedly moved towards the implementation of an alternative strategy for rural development. In particular, it is worthy to mention the Ley de Participación popular (Law of popular participation) and the Estrategia de Energía rural (Rural energy strategy). The law of popular participation, promulgated on $20^{\text {th }}$ of April 1994, recognizes indigenous communities in rural and urban areas of the country, establishes mechanisms of social support, aims to redistribute resources equally among all the inhabitants, and finally provides municipal governments with territorial jurisdiction by transferring responsibilities in the areas of health, education, roads and micro-irrigation and natural resources. In other words, this law provides the financial support for local authorities to fund projects for local development. What's more the rural energy strategy aims to integrate renewable energy with conventional sources of energy. According to Miguel Fernandez, this scheme allows adjustment of electrification programs to the characteristics of rural areas and finally integrates rural development, quality of life, environmental management and energy technology in a complementary way. That strategy is based on three pillars: i) co-financing that aspires to mix state and private funds, ii) a broad technological base that incorporates renewable energy in the rural context, and finally, iii) the demand management considered as a process identification as well as satisfaction of energy demands. The problem of access to energy by the low-income strata of Bolivian society also raises a crucial discussion about the trade-off between economic efficiency and equity. According to Enrique Birhuett, director of IDTR project, in the case of Bolivia the measures based on the so-called fundamentalism of market promoted by the international institutions in the decades of ' 80 and ' 90 (capitalization and privatization of services and infrastructure and liberalization of capital markets), were not balanced simultaneously with measures of social equity. In fact, in 1997, natural gas and electricity networks were almost totally privatized. In 2002 more than $90 \%$ of the national power structure was already in private hands. Finally between 1999 and 2000 the three remaining refineries present in the country were privatized. Such a process boosted the inequality in Bolivian society and its evolution over time opened gaps and remarkable social tensions. The neo-liberal reforms permitted the entry of several new companies into the electricity market, however, it was shown that electric facilities had not spread to many rural areas and the fees exceeded the capacity to pay them for a great part of the population (mainly in rural and urban peripheral areas). Due to the pressure of social and indigenous movements, a new season of policy was inaugurated when Evo Morales Aima, a former trade unionist of coca-leaf workers (cocaleros) with aymara indigenous origins, took the power in 2005. Morales' executive sharply rejected the neo-liberal framework proposed by the so-called Washington Consensus. The immediate results were the re-nationalizations of many company involved in the energy sector and the creation of social initiatives aiming to reduce the gap in term of energy access existing between urban and rural zones. One of 
those measures was the introduction of a tarifa dignidad (dignity fee), a legislative framework to control the cost of electricity in rural areas in order to improve the access of the poorest strata of countryside population to energy. The normative framework in Bolivia and in Latin America in general has never been particularly favourable for the production of renewable energy. However, as results of this new trend of the last two decades, Bolivia has been a pioneer in the experimentation of distributed energy production, especially in rural areas. Thanks to the adoption of an innovative off-the-grid model, Bolivia has been carrying out the largest program of rural electrification in the region. This unexpected achievement was in part due to the implementation of big projects supported by international institutions such as the World Bank and the BID (Inter-American Development Bank) and a strong commitment by the Bolivian government. The program "Electricidad para Vivir con Dignidad" (Electricity to live with dignity) was one of the actions taken in that framework [25]. One of the most important purposes of the program was to increase the extension of electricity networks in order to supply rural populations with no access to electrical infrastructure. Moreover, the program aimed to cover the urban peripheral areas by expanding the existing electrical connections and low voltage networks for new users. However the most interesting and innovative aspect of that program was the strong financial commitment in fostering the use of RE. In fact, the project allowed the implementation of renewable and alternative energy sources such as photovoltaic systems, wind, micro-hydroelectric and the efficient use of biomass. Those systems were supposed to cover the ambitious figure of approximately 180,000 rural households throughout the country. According to prof. Eduardo Lorenzo, this is the biggest project ever done in rural areas in developing countries. He has been in charge of the technical specification of the most important part of the program (IDTR project) and had the opportunity to know personally all the people involved in the planning at institutional level as well as firm level. Prof. Lorenzo claims that rural electrification in Bolivia has been always strongly influenced by the skills of specific persons involved in the specific project. The real novelty of such a project is that, due to the great number of people involved at different levels, it has been mandatory to include a sort of quality control that gave room to a standardization of procedures, tenders, routines and planning. In that sense, Bolivia represents a sort of experiment in massive rural electrification strategy. The massive use of renewable energy in rural areas was designed also to boost the social uses of electricity. According to the Deputy Minister for Electricity and Renewable Energy, Mr Miguel Gastón Yague Chirveches, "Providing electricity not only means improving the living conditions of household and individual, but also contributing to ameliorate the standards of health and education and increase the use of electricity for community benefit, productive activities and education" [25]. The program, indeed, pointed to a radical improvement of the health services and education through the provision of electricity to schools and rural health centres. Furthermore, it allowed the installation of electricity infrastructures in public buildings, provincial markets, municipal sports fields and other social structures. It is not hard to understand that the provision of electricity in rural zones can be seen as an input of production. Irrigation, refrigeration, processing and grinding food, are all activities that require electricity to increase productivity. From that point of view the improvement of local competitive capabilities can be considered as a further strategic achievement of the program. That dynamic is very interesting because, as we already pointed out, the development of local infrastructures and productive potential related to territory is one of the pillars of the endogenous development framework [31]. 
The project is divided in five sub-projects:

- IDTR - Infraestructura Descentralizada para la Transformación Rural (Decentralized infrastructure for rural transformation). This sub-project provides access to electricity with photovoltaic systems financing $60 \%$ of the cost of a PV System (PVS), while the users must contribute the remaining $40 \%$ which is payable over three years. There are also agreements with municipalities and prefectures with varying percentages. The equipment is installed by a contractor (local firm) and undergoes maintenance for four years. This new model for PVS market is called Medium-term Service Contract (MSC). Such a contract permits a good balance between the necessity of the local firms to minimize the financial risk and the desire of government to maximize the control. The MSC allows the contractors to provide services of maintenance during four years from the installation of the PVS, at which time other suppliers or the users themselves can compete to guarantee the correct functioning of the systems. The rural areas in which the PVS have been installed were divided in 14 zones and afterward were bid out in tender. In order to minimize the public subsidy each area was awarded to the bidder promising to cover the largest number of users at a given total subsidy per zone. More than 200 local firms were contacted and half of them led to 14 consortia of SMEs. That mechanism of tender was particularly successful, achieving a $25 \%$ gain in efficiency on average and demonstrating that the bidders know local markets better than local institutions [32].

- GTZ: This sub-project was designed for peripheral urban areas and rural areas where large segments of the population have no electricity supply, despite the existence of electricity infrastructure in the area. This program is under the framework of an agreement between the government of Bolivia and the German Technical Cooperation Agency GTZ. By a first call (2005), it has benefited 20,000 households with access to electricity. A second call will benefit in addition to 30,000 homes (2010).

- $\underline{K f w}$ : This sub-project aims to implement 17 micro-hydroelectric plants in rural isolated areas far from the standard electricity network. The project counts with an investment of 5,112 million Euros. All the plants are supposed to be constructed by local companies, which will be comprised of personnel from the involved communities. The project of each plant relies on a co-financing agreement between the Ministry of Public Works and Services through the Vice Ministry of Electricity and Renewable Energy (VMEEA) and the Local Prefectures.

- Euro-Solar: This sub-project allows the installation of 59 hybrid systems (PVS-wind) for the operation of computer equipment, refrigerators, water purifier, battery charger, satellite antenna and IP telephony in the beneficiary communities. In the initial phase, the installation of 45 kits for electricity production will benefit 4,523 families in isolated communities in five departments [33]. The project also includes the training of local personnel for the maintenance and management of the systems.

- UNDP: This sub-project aims to remove institutional, financial and technological barriers to achieve the successful implementation of electrification projects using renewable energy in rural areas. As in the sub-projects previously described, the program allows the funding of micro-hydroelectric plants and Photovoltaic Systems. 
Looking at the strategy and the actions undertaken by Bolivian public institutions, we can conclude that much effort has gone into fostering local competences and social improvements using renewable energy. As we are interested in the dynamic of change and innovation at several levels we can sum up schematically the highlights of the information collected about the public intervention in the renewable energy sector. The following table shows the main features of each sub-project classified in four dimensions:

Table 1 Interpretation scheme for Governmental Funded Projects

\begin{tabular}{|c|c|c|c|c|}
\hline Sub-Project & $\begin{array}{l}\text { Technological } \\
\text { Dimension }\end{array}$ & $\begin{array}{l}\text { Institutional } \\
\text { Dimension }\end{array}$ & Firms Dimension & Social Dimension \\
\hline IDTR & $\begin{array}{l}\text { Innovative Service } \\
\text { provision through } \\
\text { Off-Grid } \\
\text { technologies }\end{array}$ & $\begin{array}{l}\text { Innovative } \\
\text { funding scheme } \\
\text { (MSC) }\end{array}$ & $\begin{array}{l}\text { Fostering local } \\
\text { entrepreneurship } \\
\text { and capabilities }\end{array}$ & $\begin{array}{l}\text { Energy for social uses } \\
\text { and increment of } \\
\text { productivity }\end{array}$ \\
\hline GTZ & - & - & - & $\begin{array}{l}\text { Inclusion of marginalized } \\
\text { urban dwellers }\end{array}$ \\
\hline \multirow[t]{2}{*}{ Kfw } & $\begin{array}{l}\text { Innovative micro- } \\
\text { hydroelectric } \\
\text { technologies }\end{array}$ & - & - & $\begin{array}{l}\text { Community participation } \\
\text { in planning and } \\
\text { construction }\end{array}$ \\
\hline & & & & $\begin{array}{l}\text { Ownership of local } \\
\text { infrastructures }\end{array}$ \\
\hline Euro-Solar & $\begin{array}{l}\text { Innovative hybrid- } \\
\text { technologies }\end{array}$ & - & - & Energy for social uses \\
\hline PNUD & $\begin{array}{l}\text { Innovative micro- } \\
\text { hydroelectric and } \\
\text { PVS technologies }\end{array}$ & - & - & Energy for social uses \\
\hline
\end{tabular}

Finally we can conclude that the positive and negative aspects of governmental action seem to be:

- Strengths of public action: Governmental initiatives have pointed on rural development through the use of sustainable energy. This fact represents an exception in less developed countries and may be a model for the formulation of alternative actions and policy in other regions or sectors. As it has been already stressed, the energy in rural areas is viewed as an input of local production but also as a mean to improve basic services like health and education. The idea of energy for social uses is particularly interesting for two reasons. Firstly the social dimension of such a project encourages the diffusion of clean technologies among local communities. It is out of doubt that in the last two decades renewable energy has been becoming more and more popular in rural zones. In fact, the possibility to improve public services augments the acceptance level of uncommon technologies. 
On the other hand, the ownership of the infrastructures promotes the awareness of local people about the problems related to the use of energy. In many rural communities, especially among young people, there is an increasing interest in the management of PVS.

- Weaknesses of public action: Even though particular attention has been paid to involve local prefectures and private capital, the general impression is that the implemented actions are still too dependent on foreign financial aid. Bolivia seems to be not yet able to design and carry out renewable energy policies without a strong commitment of international cooperation. Furthermore the strong expenditures carried out in those development programs were not conducted with the support of local education system. In other words, public actions did not point to fund R\&D projects in local firms or universities. Those projects have been fostering the local firms' competences. On the other hand they seem to neglect, at least officially, the role of Bolivian universities. Actually, none of the mentioned projects formally involved academic research groups/centres.

\section{Local firms and knowledge infrastructure}

The interest in RE in Bolivia, especially for PVS, dates back to the '80s. During the last two decades that interest has been clearly increasing to such an extent that it is currently estimated that in rural areas of Bolivia there are about 20,000 installed PVS. That achievement was possible thanks to two main factors: i) the development of local technological and organizational capability and ii) the international cooperation aid. Virtually all the local subjects, basically micro-firms and NGOs, involved in the RE sector have a similar story. Those subjects were born from the interest of local technicians, academic personnel or people involved in social organization focused on the problems of rural areas. Osvaldo Peña, for instance, is the owner of a micro-firm that installs and repairs PVS in many rural zones of central part of Bolivia. Since 1990, Pena's company SIE (Servicios integrales de Energia S.A), has installed about 8000 PVS and participated in several international programs such as the already mentioned IDTR. Even though he has never had formal any contact with universities or formal education structures, his micro-firm acquired a strong technical knowledge in the field of PVS thanks to contact with local and international NGOs that were working in the rural electrification program. Another emblematic case is the example of Prosol. This micro-company was founded by Alvaro Fontanilla, an anthropologist interested in improving the quality of the life of people living in the rural areas. Alvaro approached the PVS technology thanks to the work of German cooperation in Bolivia. At that time, the beginning of the ' 90 s, the GTZ (Gesellschaft für Technische Zusammenarbeit, German agency for technical cooperation) was trying to implement the first program of rural electrification in isolated zones of the departments of Cochabamba and La Paz. Prosol and GTZ created a workshop to build and repair electrical components for simple PVS. After a few years Prosol was able to produce in-series switches and battery regulators as well as to assemble and install basic PVS. The knowledge acquired by such a program of technological transfer allowed Prosol to begin to sell and install PVS in several isolated municipalities in many areas of Bolivia. According to Mr Fontanilla, the activity of Prosol had to face two main issues. The first one was the lack of local personnel able to manage the PVS and guarantee the sustainability of the systems. Secondly, due to the endemic poverty of rural zones, the users had very limited financial resources. The problem of sustainability and maintenance of the systems represents one the most critical 
barriers for the rural electrification program. The rural zones in Bolivia are very poor and often hard to reach. In many cases, when a system is broken, the people prefer to let it go instead of travelling to the closest city, buying spare parts and repairing it. One of the possible solutions is to create a sense of responsibility at community level. In many cases, especially in the Andean zones, traditional communities have a horizontal hierarchical organization that allows the sharing of the fundamental means of subsistence such as land, tools or public infrastructure. According to Prosol, the most successful cases in terms of the sustainability of the systems have been those in which it was possible to identify the key persons of the community and convince them that the well-working of PVS was crucial to improve their life. On the other hand, the problem of the lack of financial resources was partially solved by implementing an innovative micro-credit program involving local municipalities. It has been noted that the financial involvement of the families in rural communities increased the awareness and the sustainability of the systems in the long run. In other words, when the people pay according to their incomes they are more disposed to take care of the systems. Another interesting example is the case of Energética. Since its creation in February 1993, Energética, has attempted to promote greater and more rational use of RE in Bolivia. The idea behind their action is that RE is key to achieving sustainable development in many sectors of the Bolivian economy in urban zones as well as in rural areas. Their philosophy is well described by their motto: "Both the poor and the rich must overcome the illusion that more energy is better... the energy and equity have to go hand in hand"[34]. Although its internal organization is shaped more on a private company rather than a non-profit institution, formally Energética was an NGO. They focus on rural energy development and training with a particular attention to institutional change. Furthermore, in the last decade they dedicated several efforts to promote a culture of entrepreneurship among local private firms related to the renewable energy sector. Unlike Prosol, Energética was created by people coming from the Universidad Mayor de San Simón of Cochabamba (UMSS of Cochabamba). For those reasons the organization is focused not only on technological issues but also on sociological aspects related to environmental sustainability and poverty. According to Tania Vazquez, one of the founders of the NGO, during the ' $90 \mathrm{~s}$ Energética managed to spread awareness about RE in several sectors of Bolivian society. They used many different means such as rural radios, television advertisements, conferences and, especially in rural areas, pilots and demonstrations. At the same time they have been participating in the most important national and international projects of rural electrification in Bolivia. Energética has so far installed about 14,000 PVS in public and private infrastructure in all Bolivia's departments. At the beginning of its activity the installations were carried out by the engineers of the NGO. As the projects have become bigger they were compelled to create teams of skilled workers able to assemble and install PVS all over the country. That process has been crucial to accumulate the needed knowledge that led to the creation of independent micro-firms. Moreover, the increase of photovoltaic installations in the country generated a critical mass of users in rural areas that, once the initial demand of access to energy was satisfied, had to face the challenge of sustainable use of this energy. In other words, the users needed a network of companies able to provide technical assistance and service. According to Miguel Fernandez, current director of Energética, the volume of the existing facilities is enough to develop a model of Micro Maintenance Companies that can provide adequate service and access to spare parts. This awareness led to the creation of the programme "Micro Business Maintenance of PV Systems", born from the collaboration between Energética and the Dutch ETC Energy 
foundation, which aimed to create a network of micro enterprises based on local expertise, thus responding to demands within their communities and municipalities. Although this kind of initiative was normally designed for the PVS market, it is possible to expand it in order to cover other renewable energy sources such as bio-digesters or improved traditional kitchens. One of the most interesting features of the project is that it relies not only on the experience of Energetica's technicians but also on the technical schools present in the area as well as the university UMSS. In that sense the NGO plays as a catalyser to activate the transfer from the local knowledge infrastructures to the region. In 2009, according to Energética, 9 micro enterprises have been created. However the NGO expects to create between 30 and 40 independent businesses. Those micro enterprises are supposed to provide technical service and maintenance but also offer other type of applications and accessories like mobile phones, radio and TVs. The relationships between NGOs like Energética and education institutions are not simply limited to training local personnel. In fact, they seem quite well integrated in the larger network of organizations, research centres and universities that are working in the same field all around the world. In August of 2009, thanks to the support of CYTED programme (Ibero-American Development Programme for Science and Technology), Energética managed to install a photovoltaic system of $2.7 \mathrm{kWp}$ and connect it to the national electric network. The CYTED programme is "an intergovernmental multilateral Science and Technology cooperation programme, which aims to combine different perspectives and visions to promote cooperation in Research and Innovation for the development of the Latin America region"[35]. In this particular case the programme gathered contributions from the Energy and Electronic departments of the Polytechnic University of Madrid in Spain, Sao Paulo in Brazil and Perpignan in France. That programme represents a pilot study that have two basic objectives: i) improve local capabilities in the design and construction of medium-power PVS, ii) provide an example to show that it is possible to produce clean energy and sell it to the national electric network in Bolivia. However, according to Energética's staff, a lot of work is still needed, for the future, in particular, it is crucial:

- To acquire further know-how and analyse how the context is going to respond to those technologies.

- To analyse the response of the electricity network to the injection of low voltage energy.

- To build a legal framework for expanding similar initiatives and propose policies of incentives.

- To create a strategic alliance with key institutional players: Vice Ministry of Electricity and Alternative Energy as head of sector, Bolivian national companies, regulatory institutions, local governments, prefectures, universities and environmental institutions in the region.

The network approach seems to be successful particularly when competences, coming from heterogeneous subjects, are able to trigger the local potential. However, according to Javier Alaga, professor of UCB (Catholic University of Bolivia), the Bolivian universities system lacks coordination. There is no sharing of projects or common initiatives neither in research nor in relation with the private sector. On the other hand, UCB participates in international projects that aim to strengthen the potential of Latin American Universities. One of those 
programmes is the Joint European-Latin American universities renewable energy project that groups several universities in a cooperation scheme "with the aim of fostering innovative labour market-oriented educational and research approaches in the field of renewable energies" [36]. However, even though the situation is slowly improving, Bolivian universities still have serious structural problems. According to prof. Eduardo Lorenzo, the salaries of Bolivian professors are extremely low and the lack of research infrastructures is still overwhelming. Without appropriate facilities and means it is hard to undertake tests in isolated zones or carry out research activities characterized by medium-high expenditures. We can now extrapolate a sort of pattern according to which local proto-entrepreneurial initiatives become active micro enterprises. The pattern clearly presents three steps of evolution of local micro firms: i) Firstly we witnessed the creation of local initiative promoted by social organization (Prosol case), local technicians (SIE case) or skilled people coming from the academia (Energetica case). In this early stage the activity of those organization is based mostly on local and limited actions; ii) Secondly those subjects achieve a sufficient level of know-how that allows them to have access to international aid programmes. This jump triggers a dynamic of knowledge accumulation that permits an increase in their ability to compete at national level; iii) finally, the original organizations formalize their structures in different ways such as NGOs or small profit companies. In this scenario the roles of Bolivian NGOs seems to be a bridge between international aid programme, local providers, micro companies and the users.

\section{Indigenous communities and energy production: the case of Kami}

Bolivia, more than other countries in the region, still conserves an almost intact indigenous social life. Due to their isolation, many areas of Bolivia only received a small influence by Spanish conquerors. Consequently nowadays in many rural areas there is a cohabitation of national law with community law, which frequently is a source of strong conflicts between local groups and public authority. Furthermore, during nearly four centuries of colony under the Spanish crown and almost two hundred years of turbulent republican life, indigenous society was considered archaic and savage. Although indigenous population always was an overwhelming majority, Quecha, Aymara, Guarani and many other native groups have never had the opportunity to participate in the administration of the republic. However in recent decades there has been a renaissance of indigenous community in Bolivia that led to the formation of the first national government in the region ruled by a native, Evo Morales. At the same time many NGOs, academics and public institutions became interested in reviving this ancient world. According to Ruth Volgger, national director of the Italian NGO Ricerca e Cooperazione for more than 20 years, restoring traditional knowledge is not simply an anthropologic task, rather it is a way to rediscover more efficient techniques of production and management of the land. Volgger has been working for many years in the field of alimentary security in the indigenous communities of the Bolivian plateau. She claims that in the age of the Incas quality and biodiversity of food in Bolivia were much higher than during the colonial period. That is because indigenous populations developed a very efficient system of terraces over thousands of years in order to take the maximum advantage from the poor soil of the Bolivian plateau. Moreover, they were able to rotate cultivations and allocate resources according to the season and the altitude of the crops in order to assure a good harvest over the year. Bolivian in the pre-colonial period rarely suffered famine. When Spaniards arrived, they drove out most of indigenous population from their original territory and forced them to work in silver mines. That process broke the 
traditional organization of the land causing starvation and a sharp decrement in terms of quality of life. Today people like Ruth Volgger are working to restore ancient knowledge in a new way. This new vision is based on the belief that a dialogue between local and traditional knowledge, academy and enterprises, is possible. They call this approach dialogo entre saberes, dialogue between knowledges. That dialogue does not reject modern technology; rather it attempts to combine different kinds of knowledge in a non-invasive way to achieve new solutions. This perspective underlines the importance of social acceptance of technology that is crucial to consider the technical progress as a qualitative improvement rather than a mere quantitative growth. An example of this approach is certainly the case of Kami. Kami is a little Aymara community in the Bolivian Andes between the departments of La Paz and Cochabamba. Kami was a place of peasant farmers before it became a mining centre. However, because of its isolation and the strong fluctuation in mineral's prices, a lot of people were compelled to immigrate to a more populated and prosperous zone in the country. In 2000 the local community of Salesian of Don Bosco started an ambitious project to improve the conditions of the local population. The original idea was to build a microhydroelectric plant to provide electricity to the community and, additionally, raise money selling energy to the neighbours to finance social projects such as schools, public infrastructures and education. A first attempt consisted in building a micro plant of $500 \mathrm{~kW}$ (enough to provide electricity to more than 200 families) with the help of the EU. This first experiment did not fully fulfil the expected results. At that time, in fact, it was contracted to an external company, which triggered many conflicts among the community's members. In this first stage the local community did not feel part of the project and rejected to participate actively. Alberto Schiappapietra is an engineer and national director of GVC, an Italian NGO that promotes rural development in Bolivia. For about 3 years he has been working in Kami as a volunteer and he had the opportunity to follow the construction of the plant in Kami. I met him in 2007 and I contacted him again for a phone interview in March 2010. According to Alberto the project took off when it was decided to use only local workforce. This second phase relied on a loan by the Italian bank Banco San Paolo, achieved thanks to the help of the Italian Salesian community. In the Alps micro-hydroelectric technology has been widely used since the beginning of the 20th Century. Thus with the support of local electrical companies in Val D'Aosta (Italy), two old turbines of $2 \mathrm{MW}$ were reassembled and sent from the Italian Alps to Kami. After more than three years of negotiation with the Aymara communities of Kami, the design of the plant was complete. The work consisted in the excavation of a $4 \mathrm{~km}$ long tunnel for the channelling of the water of the local river. The water was then channelled in two turbines installed in an engine room connected to the electricity network. All the work was carried out using local workforce. In fact the tunnel was divided into 14 sections of 500 meters and each piece was assigned to a group of workers selected by the community. The work took more than three years and involved about 200 persons. The evolution of the work required the development of many different capabilities that led to the creation of at least 20 mini companies specialized in digging, construction and electricity (learning by doing [37]). Most of those groups, due to the experience acquired in Kami, were able to export their capability, working in other projects all around the country. For example, the members of the community that gained knowledge in digging were quickly able to compete in the mining sector at national level. However Mr Schiappapietra claims that the most important innovation in the community was the way the people self-organized the work. Through a mutual interaction, the people learnt to carry out a complex job like the construction of a hydroelectric plant with a 
minimal external support. At the end of the project, in order to prove that the water used by the plant was still pure, the community constructed a pool for fish farming of local trout. Finally, the energy produced was sold through the connection to the national network. Recently, in order to overcome the losses caused by the old transmission lines that connect Kami to the rest of the country, the community has put on a team specialized in building electrical lines. In the spring of 2011 with the help of the Italian company TERNA, $37 \mathrm{~km}$ of power lines were ready for the test [38]. What happened in Kami illustrates that a sustainable development is possible by exploiting local potential. In the case of Kami, the learning process has been triggered by the interaction of foreign actors with a long experience in micro-hydroelectric technology that provided the basic technology to start the project. Then, through a process of learning by doing, the community organized itself to adapt the novelty to the local environment. Such a process endowed the territory not only with clean electricity but also with new capabilities that can foster the development of the zone. The revenue of the plant are used to pay the local personnel involved in the functioning of the machines, but also to improve local education and promote social programs. That dynamic represents a virtuous circle that would be able to generate new capabilities and further improvements.

\section{Improving local capabilities through international cooperation policy}

As it has been shown above, international cooperation for development has a determinant influence in many projects in Bolivia. In all the cases we have illustrated that international support has, directly or indirectly, been fundamental at least in the phase of financing of the initiatives. Even though it is without a shadow of doubt that foreign aid is crucial in many fields, especially in the poorest areas of the country, the effectiveness of these actions is often considered controversial. Nowadays in Bolivia there are thousands of foreign NGOs working in several different sectors and very few of them have witnessed a real positive impact on local reality. According to Ruth Volgger, the most serious problem that international NGOs face is a complete lack of a rigorous methodology necessary for the identification of local necessities and, above all, for the assessment of the outcome of their actions. Moreover, they basically are not big enough to carry out a multidisciplinary analysis of the local context because of their limited resources in term of professional personnel. prof. Lorenzo also agrees on the fact that local or international NGOs cannot afford big projects such as the electrification of rural zones in Bolivia. They simply do not have the technical capacity and financial resource to have an effective impact. The private sector on the other hand is not interested in rural electrification. They tend to dedicate, indeed, the worst resources they have. According to Nicola Briguglio, one of the founders of Ricerca $e$ Cooperazione, international NGOs often tend to have the misleading conviction that their actions are the most appropriate to solve many different problems at the same time. In other words they often miss a systemic vision of local context. It is also important to note that many cases reveal that international donors often have several political interests such as opening new markets for their product or achieving privileged access to natural resources. Beyond any criticisms the cases analysed above show clearly that international cooperation is very useful when:

- It helps to develop local potential instead of simply importing external knowledge and technology. The case of Energética and Kami are emblematic in this sense. 
- It supports local institutions in fostering local capability and local entrepreneurship. The case of the IDTR project is a very good example in that sense.

- It promotes collaboration and networking rather than funding. The case of the EU American network JELARE is an example of this kind of initiative.

\section{Conclusion}

Although the Bolivian case presents several interesting characteristics, we cannot identify a well-developed system of innovation in the RE sector. Rather it is possible to affirm that the sector is in an initial phase that could be named proto-innovation system. Even though there have been many important advances, especially in the PVS technology, Bolivia still miss two important components of an IS that are a strategy for innovation policy and an adequate education system. The case seems to confirm the need for better coordination at the national level between those stakeholders involved in the development of a local renewable energy industry found elsewhere in other developing countries [39]. It is now quite clear that one of the most important factors in the process of catch-up is the accumulation of strategic knowledge [40]. The case shows that the absorption capacity of the country depends mostly on local and often isolated subjects. In other words, the systematization of knowledge and its organization in order to achieve coordinated actions to trigger the local development processes is still a missing piece in the puzzle and, probably, the most important one. On the other hand, the case shows an innovative approach in using traditional knowledge in spreading clean technology and in the activation of local potential. In any case, a positive framework emerges from the analysis, which indicates what might be the future actions necessary to build an effective system of innovation for RE in Bolivia: First of all, it is crucial to invest in Bolivian Universities. Lack of infrastructures, ridiculous wages, and inexistent research programmes are insurmountable barriers for innovation in academia [41, 42]. It is crucial not only to endow Bolivian Universities with adequate tools but also to foster coordination at national and international level. The case study shows that local firms rely on foreign universities rather than local institutions. For this reason it is necessary to establish more effective connections between the productive world and academia and create quality control mechanisms, which are crucial to guarantee long-term reliability of renewable energy solutions [43]. Secondly, it is fundamental to promote renewable energy in public administration much more than it has been done until now. Bolivia has an enormous potential in terms of sun, wind and microhydroelectric energy. It is time to develop specific policies to foster the use and production of clean energy. Those policies should include the possibility of local communities financing their own projects of decentralized energy production and selling the excess energy in the case of over production. Such a process could yield to a very interesting development of traditional communities that can experiment with different regimes of ownerships and management of the plants. Finally, it is crucial to promote and sustain local firms in the urban context as well as in rural areas. It has been show that Bolivian micro-firms are able to work in the urban zone as well as in isolated traditional communities. They represent the most active actors in the framework and possess the necessary capability to understand local context. 


\section{Appendices}

Table 2 List of interviewees

\begin{tabular}{|c|c|}
\hline Name & Position \\
\hline Miguel Fernandez & Director Bolivian NGO, Energética \\
\hline Tania Vazquez & Co-founder of Energética \\
\hline Javier Aliaga Lordemann & $\begin{array}{l}\text { Profesor at Instituto de Investigaciones Socio-económicas } \\
\text { (IISEC) de la Universidad Católica Boliviana (UCB) }\end{array}$ \\
\hline Osvaldo Ivailo Peña Treneva & SERVICIOS INTEGRALES DE ENERGÍA S.A. \\
\hline Ruth Volgger & National Manager Italian NGO, Ricerca e Cooperazione \\
\hline Nicola Briguglio & Responsible in Italy for Bolivia - Ricerca e Cooperazione \\
\hline Lorenzo Perone & National manager ISF (Ingeneria sin Fronteras Spain) \\
\hline Alberto Schiappapietra & National manager Italian NGO, GVC \\
\hline Eduardo Lorenzo & Professor at Polytechnic University of Madrid \\
\hline Alvaro Fontanilla & Director of Prosol \\
\hline Pascual Maldonado & Professor at Universidad San Andres La paz. \\
\hline Enrique Birhuett & Director IDTR Programme \\
\hline
\end{tabular}

\section{References}

[1] Hart S. Taking the Green Leap to the Base of the Pyramid. In: London T, Hart SL, editors. Next Generation Business Strategies for the Base of the Pyramid New Approaches for Building Mutual Value. Upper Saddle River, New Jersey: Pearson Education; 2011. p. 79-101.

[2] London T, Hart SL. Reinventing strategies for emerging markets: beyond the transnational model. Journal of International Business Studies. 2004;35:350-70.

[3] Kaplinsky R. Schumacher meets Schumpeter: Appropriate technology below the radar. Research Policy. 2011;40:193-203.

[4] Geller H, Schaeffer R, Szklo A, Tolmasquim M. Policies for advancing energy efficiency and renewable energy use in Brazil. Energy Policy. 2004;32:1437-50.

[5] Brown JS. Innovation Blowback: Disruptive management practices from Asia. McKinsey quarterly. 2005;1.

[6] Martinot E, Chaurey A, Lew D, Moreira JR, Wamukonya N. Renewable Energy Markets in Developing Countries*. Annual Review of Energy and the Environment. 2002;27:309-48.

[7] Chien T, Hu J-L. Renewable energy and macroeconomic efficiency of OECD and nonOECD economies. Energy Policy. 2007;35:3606-15. 
[8] Zhang L, Yang Z, Chen B, Chen G. Rural energy in China: Pattern and policy. Renewable Energy. 2009;34:2813-23.

[9] Peidong Z, Yanli Y, jin S, Yonghong Z, Lisheng W, Xinrong L. Opportunities and challenges for renewable energy policy in China. Renewable and Sustainable Energy Reviews. 2009;13:439-49.

[10] Liming H. Financing rural renewable energy: A comparison between China and India. Renewable and Sustainable Energy Reviews. 2009;13:1096-103.

[11] Islam AKMS, Islam M, Rahman T. Effective renewable energy activities in Bangladesh. Renewable Energy. 2006;31:677-88.

[12] Karekezi S, Kithyoma W. Renewable energy strategies for rural Africa: is a PV-led renewable energy strategy the right approach for providing modern energy to the rural poor of sub-Saharan Africa? Energy Policy. 2002;30:1071-86.

[13] Himri Y, Malik AS, Boudghene Stambouli A, Himri S, Draoui B. Review and use of the Algerian renewable energy for sustainable development. Renewable and Sustainable Energy Reviews. 2009;13:1584-91.

[14] Deichmann U, Meisner C, Murray S, Wheeler D. The economics of renewable energy expansion in rural Sub-Saharan Africa. Energy Policy. 2011;39:215-27.

[15] UNDP. Human Development Report. NY: ONU; 2008.

[16] Arocena R, Sutz J. Looking at national systems of innovation from the South. Industry \& Innovation. 2000;7:55-75.

[17] CEPAL. Innovar para Crecer. Desafíos y oportunidades para el desarrollo sostenible e inclusivo en Iberoamérica. Santiago de Chile: UN; 2009.

[18] RC. Relazione Terza annualità. Progetto Norte Potosí - COD: 7529/RC/BOL. Roma: Ricerca e Cooperazione; 2007.

[19] Schienstock G. Sustainable Development and Regional Dimension of Innovation System. In: Weber M, Hemmelskamp J, editors. Towards Environmental Innovation Systems. Berlin, Germany: Springer; 2005.

[20] Alam Hossain Mondal M, Kamp LM, Pachova NI. Drivers, barriers, and strategies for implementation of renewable energy technologies in rural areas in Bangladesh-An innovation system analysis. Energy Policy. 2010;38:4626-34.

[21] Brent AC, Kruger WJL. Systems analyses and the sustainable transfer of renewable energy technologies: A focus on remote areas of Africa. Renewable Energy. 2009;34:177481.

[22] Lundvall B-A, Vang J, Chaminade CaJ. Innovation system research and developing countries. In: Lundvall B-A, editor. Handbook of Innovation System and Developing Countries. Cheltenham, Uk: Edward Elgar; 2009.

[23] MCB. Ministerio de Culturas. In: Culturas Md, editor.2010.

[24] WEF. The Global Competitiveness Report 2009-2010. Geneve, Switzerland: World Economic Forum; 2009. 
[25] VMEEA. Programa "Electricidad para Vivir con Dignidad" - Memoria Informe 2009. La Paz, Bolivia: Viceministerio de Electricidad y Energías Alternativas; 2009.

[26] OECD. Oslo Manual. The Measurement of Scientific and Technological Activities. Proposed Guidelines for Collecting and Interpreting Technological Innovation Data. Paris1992.

[27] Gudynas E. La Pachamama: ética ambiental y desarrollo. Le Monde Diplomatique. 2010:4-6.

[28] Blanco B. Los efectos de los cambios climáticos en las relaciones de reciprocidad entre los pueblos indígenas y la Pachamama en Bolivia. In: Ulloa A, editor. Mujeres indígenas y cambio climático. Bogota: Fundación Natura. UNODC.UNAL.; 2008. p. 195.

[29] Becker CD, Ostrom E. Human-Ecology and resource sustainability - The importance of institutional diversity. Annual Review of Ecology and Systematics. 1995;26:113-33.

[30] MRE. El vivir bien como respuesta a la Crisis Global. La Paz, Bolivia: Ministerio de Relaciones Exteriores; 2009.

[31] Vazquez-Barquero A. Las nuevas fuerzas del desarrollo. Barcelona, Sapin Antoni Bosch; 2005.

[32] Reiche K, Rysankova D, Goldmark S. Balanced Tender Design for Sustainable Energy Access in Difficult Markets. In: series O, editor. Washington, USA: Global Partnership on Output Based Aid - World Bank; 2007.

[33] VMEEA. Plan de visibilidad programa euro- solar. La Paz, Bolivia: Viceministerio de Electricidad y Energías Alternativas; 2008.

[34] Energetica. Energia para el desarrollo. 2012.

[35] CYTED. Ciencia y Tecnologia para el desarrollo. 2010.

[36] JELARE. Joint European-Latin American Universities Renewable Energies Project. 2010.

[37] Rosenberg N. learning by doing, learning by using. Inside the Black Box Technology and Economics. 2002;77:1-15.

[38] Terna. Terna for the Kami project in Bolivia. 2012.

[39] Urmee T, Harries D, Schlapfer A. Issues related to rural electrification using renewable energy in developing countries of Asia and Pacific. Renewable Energy. 2009;34:354-7.

[40] Cimoli M, Dosi G, Stiglitz JE. The Future of Industrial Policies in the New Millennium: Toward a Knowledge-Centered Development Agenda. International Schumpeter Society Conference 2010 on Innovation, Organisation, Sustainability and Crisis At Aalborg University. Aalborg, Denmark 2010.

[41] Arocena R, Senker P. Technology, inequality, and underdevelopment: The case of Latin America. Science Technology \& Human Values. 2003;28:15-33.

[42] Arocena R, Sutz J. Latin American universities: From an original revolution to an uncertain transition. Higher Education. 2005;50:573-92.

[43] Zhang X, Kumar A. Evaluating renewable energy-based rural electrification program in western China: Emerging problems and possible scenarios. Renewable and Sustainable Energy Reviews. 2011;15:773-9. 